\title{
Determinants of Systemic Risk: The Case of Egyptian Banks
}

\author{
Nader Alber ${ }^{1}$ \\ ${ }^{1}$ Faculty of Commerce, Ain Shams University, Cairo, Egypt \\ Correspondence: Nader Alber, Associate Professor, Faculty of Commerce, Ain Shams University, Cairo, Egypt. \\ Tel: 201-005-668-507. E-mail: naderalberfanous@yahoo.com
}

Received: January 3, 2015

Accepted: January 23, 2015

Online Published: February 25, 2015

doi:10.5539/ibr.v8n3p112

URL: http://dx.doi.org/10.5539/ibr.v8n3p112

\begin{abstract}
This paper aims at analyzing the effects of "size", "financial stability" and "equity return" on the systemic risk of Egyptian banks. This has been conducted using a sample of 11 banks (out of 14 banks listed in the Egyptian exchange), and covering the period from January 2003 to December 2013. Systemic risk is measured by "Value at Risk" that expresses the maximum loss within a q\%-confidence interval during a certain period of time. Determinants of systemic risk to be examined, may be economic, as "size" in terms of TBTF rule. They may be financial, where "financial stability" is addressed as the ability of financial system to resolve systemic risks. Besides, "equity return" is assumed as a market determinant. Results indicate that size and financial stability may affect systemic risk of Egyptian banks during research period, using cross sectional analysis, by monthly returns (1-month, $0.99 \mathrm{VaR})$ for the pre-crisis, during-crisis and all the research periods. Also, robustness check investigates the effect of financial stability, using time series analysis, by daily returns (1-day, $0.99 \mathrm{VaR}$ ).
\end{abstract}

Keywords: Egyptian banks, financial stability, equity return, size effect, systemic risk

\section{Introduction}

The performance of Egyptian banks witnesses several changes, due to changes in market structure and regulatory reforms. Table 1 illustrates major developments of Egyptian banks' performance from 2008 till 2013, as follows:

Table 1. Development of Egyptian banking performance from 2008 to 2013

\begin{tabular}{clllllll}
\hline \multirow{2}{*}{ Item } & \multicolumn{1}{c}{ Indicator } & $\mathbf{2 0 0 8}$ & $\mathbf{2 0 0 9}$ & $\mathbf{2 0 1 0}$ & $\mathbf{2 0 1 1}$ & $\mathbf{2 0 1 2}$ & $\mathbf{2 0 1 3}$ \\
\hline \multirow{3}{*}{$\begin{array}{c}\text { Capital } \\
\text { Adequacy }\end{array}$} & Capital Base to Risk weighted assets & 0.147 & 0.151 & 0.163 & 0.156 & 0.149 & 0.134 \\
& Tier 1 Capital to Risk-Weighted Assets & 0.115 & 0.120 & 0.127 & 0.130 & 0.129 & 0.115 \\
& Net Worth to Assets & 0.062 & 0.064 & 0.067 & 0.062 & 0.072 & 0.069 \\
& Nonperforming Loans to Total Loans & 0.148 & 0.134 & 0.136 & 0.109 & 0.089 & 0.065 \\
\multirow{3}{*}{ Asset Quality } & Loan Provisions to Nonperforming Loans & 0.921 & 1.004 & 0.925 & 0.946 & 0.971 & 0.989 \\
& Loans to Private Sector to Loans to Customers & 0.839 & 0.810 & 0.805 & 0.811 & 0.822 & 0.836 \\
& Return on Average Assets & 0.008 & 0.008 & 0.010 & 0.010 & 0.010 & 0.010 \\
& Earnings & 0.141 & 0.130 & 0.143 & 0.143 & 0.139 & 0.139 \\
& Return on Average Equity & 0.017 & 0.022 & 0.023 & 0.023 & 0.035 & 0.035 \\
& Net Interest Margin & 0.345 & 0.434 & 0.447 & 0.554 & 0.584 & 0.595 \\
& Liquidity Ratio: Local Currency & 0.468 & 0.410 & 0.406 & 0.511 & 0.563 & 0.570 \\
& Liquidity Ratio: Foreign Currencies & 0.122 & 0.138 & 0.180 & 0.182 & 0.219 & 0.190 \\
& Securities to Assets & 0.784 & 0.824 & 0.810 & 0.754 & 0.827 & 0.762 \\
& Deposits to Assets & 0.577 & 0.577 & 0.518 & 0.500 & 0.481 & 0.463 \\
\hline & Loans to Deposits & & & & &
\end{tabular}

Source: Central Bank of Egypt (2013) Economic Review.

The above-shown indicators may shed lights on some positive or negative changes in performance of Egyptian banks, but an important question about market reaction to these changes is still uncovered. During financial 
crises, losses tend to spread across financial institutions, threatening the financial system as a whole, while CAMEL (Capital adequacy, Asset quality, Management, Earnings and Liquidity) indicators may tell another story.

The spreading of distress gives rise to systemic risk, spillovers across institutions can arise from direct contractual links and heightened counterparty credit risk, or can occur indirectly through price effects and liquidity spirals. As a result of both, measured co-movement of institutions' assets and liabilities tends to rise above and beyond levels purely justified by fundamentals. Systemic risk measures capture the potential for the spreading of financial distress across institutions by gauging this increase in tail co-movement. (Adrian \& Brunnermeier, 2011, p. 1).

There is an extended and growing literature concerning the measurement of the systemic risk by using CDS data (available only for a few banks listed in developed countries). This type of estimation well reflects the default dependence among institutions, and it can capture the credit risk. (Lucas et al., 2011; Ang \& Longstaff, 2013).

Literature concerning with systemic risk can be divided into two categories: the "network analysis approach" and the "micro evidence approach". The first investigates and evaluates the extent to which the failure of an institution threatens the viability of its creditors (by analyzing the joint distribution of losses by all market players), while the second concerns with the effects of bank - specific variables on systemic risk.

Dragan et al. (2013) addresses that one of the most feared events in banking is the alarm of systemic risk. It can be likened to fire alarm. But unlike fire, systemic risk is not clearly defined. Moreover, unlike the firefighters who often are able to turn off the fire, bank regulators have been accused of the contribution that they had in amplifying systemic risk. Systemic risk precise meaning is ambiguous; it means different things to different people.

Bartholomew \& Whalen (1995) defines systemic risk as "an event that has an effect on the entire banking, financial and economic system, rather than just one or a few institutions". Besides, Kaufman (1995) believes that systemic risk is "the risk of chain reactions that cause collapse of interconnected institutions". Borri et al. (2014) defines systemic risk, as the risk of a collapse of the entire financial system, typically triggered by the default of one, or more, interconnected financial institutions.

Adrian \& Brunnermeier (2011) proposes CoVar, as a measure for systemic risk, that denotes the value at risk (VaR) of the financial system conditional on institutions being in distress, where an institution's contribution to systemic risk is the difference between CoVaR conditional on the institution being in distress and CoVaR in the median state of the institution, while traditional risk measures focus on the risk of individual institutions. $\triangle \mathrm{CoVaR}$ focuses on the contribution of each institution to overall system risk. The authors add (Co) to the risk measure (VaR) to stand for conditional, contagion, or co-movement.

This paper attempts to propose a framework for assessing the systemic risk of Egyptian banks. This framework elaborates economic, financial and market aspects, as three main determinants of the systemic risk. Systemic risk is measured by VaR, bank size is used as an economic determinant, and financial stability is addressed as a financial one. Besides, equity return is used as a market determinant.

In brief, this study tries to answer these three main questions:

- Does "bank size" affect its systemic risk? By other words: Is systemic risk of big banks better (lower) than that of small banks, due to TBTF (To Big To Fall) rule?

- Does bank "financial stability" affect its systemic risk? By other words: Is systemic risk of banks with high financial stability, better (lower) than that of those with low one?

- Does bank "equity return" affect its systemic risk? By other words: Is systemic risk of banks with high equity return, better (lower) than that of those with low one?

The paper is arranged as follows: after this introduction, section 2 reviews research literature that has concerned with "systemic risk", "size effect" and "financial stability". Section 3 explains how to measure research variables and illustrates how to test the hypotheses. Section 4 is for empirical work, presenting results, discussing how these results answer research questions and providing a robustness check. Section 5 summarizes the paper and provides remarks about conclusions.

\section{Literature Review}

This section tries to present some of previous work, which has been conducted in the field of "systemic risk", "size effect" and "financial stability". 
Concerning with Systemic Risk, Lehar (2005) proposes a method to measure the systemic risk of North American, European and Japanese banks by using stock market information to estimate the joint dynamics of banks' asset portfolios and computes the expected shortfall of each bank in case of default. Huang et al. (2009) measures the systemic risk by the distress insurance premium using CDS data and time - varying correlations in stock returns across 12 major US banks during the sample period 2001-2008.

Segoviano \& Goodhart (2009) investigates the individual firm's contribution to the potential distress of the system within a multivariate copula setting. It quantifies the probability of at least one extra failure given the failure in the system, to construct a banking stability index and estimate cross - border interbank dependence for tail events. De Jonghe (2010) generates a market - based measure of banks' systemic risk exposure by using Tail Beta that measures the probability of a sharp decline in a bank's stock price conditional on a crash in a banking index.

Acharya et al. (2010) proposes the Marginal Expected Shortfall (MES), to measure the contribution to systemic risk of US banks from 2007 to 2009. Martinez - Jaramillo et al. (2010) applies the systemic risk network model to estimate the distribution of losses in order to perform stress tests and to investigate the effect that different levels of correlation have on the distribution of losses. This has been conducted using data from Mexican banks during the period from 2007 to 2009.

Markose et al. (2010) applies an agent - based modelling to a financial network by using CDS data of the top 25 US banks and use simulation results to devise an operational measure of systemic risk. Huang, Zhou, and Zhu (2010) develop a systemic risk indicator measured by the price of insurance against systemic financial distress, based on credit default swap (CDS) prices.

Adrian \& Brunnermeier (2011) indicates that leverage, size, and maturity mismatch predict systemic risk contribution, as measures by the proposed measure $\Delta \mathrm{CoVaR}$. Following this methodology, Borri et al. (2014) estimates the systemic risk contribution of Italian - listed banks for the period from 2000 to2011. Findings show that size is the main predictor of a bank contribution to systemic risk. However, in the post - Lehman period, leverage is also an important predictor of systemic risk.

Schaeck et al. (2013) decomposes the correlation of bank stock returns into a systemic risk and diversification activities components, as applied on the 200 largest BHCs in the U.S. using weekly returns. Results indicate that decomposition permits us to estimate the marginal gains from diversification, which turn out to be rapidly declining with bank size. Moreover, Laeven et al. (2014) estimates SRISK over the period from July 2007 to December 2008 and covers large banking firms from both the United States and Europe. Results shows that large banks, on average, create more individual and systemic risk than smaller banks. The risks of large banks are especially high when they have insufficient capital, unstable funding, engage more in market-based activities, or are organizationally complex.

Concerning with Size Effect, Carvallo \& Kasman (2005) investigates the cost efficiency of a sample of 481 Latin American and Caribbean banks in 105 countries over the years from 1995 to 1999 using a stochastic frontier model (SFA). The authors use three inputs: loans, deposits, and other earning assets and three prices of factors of production: the price of labor, the price of purchased funds, and the price of physical capital. Results indicate that very small and very large banks are significantly more inefficient than large banks.

Sahut \& Mili (2009) investigates the distress and subsequent merger decisions for 330 banks from the MENA region during the period 2000-2007. Empirical evidence indicates that monetary policy indicators do not really affect bank distress and shows that distressed state-owned banks and large-sized banks are less likely to be a target in a merger transaction. Berger \& Bouwman (2011) shows that capital helps small banks to increase their probability of survival and market share at all times (during banking crises, market crises, and normal times). Besides, capital enhances the performance of medium and large banks primarily during banking crises.

Anis \& Sami (2012) investigates the cost efficiency of 17 Tunisian universal banks over the period 1997-2006 and examines the influence of environmental variables on the bank cost efficiency. Using a parametric approach stochastic (SFA), results show that small and medium-sized banks are more efficient than large ones. Besides, Alber (2014) investigates the effect of "size" on the performance Egyptian banks. This has been conducted using a sample of 10 banks, and covering the period from the first quarter 2003 to the fourth quarter 2011. Results indicate that big banks have better performance (according to capital adequacy, asset quality and earning) than small ones.

Recently, Chaudron \& de Haan (2014) analyzes the size of failures using 3 databases as applied on 4 banking crises in U.S., Japan. Norway and Turkey. Results show significant discrepancies among these databases and 
indicate that Laeven-Valencia database seems to be the most accurate one in the dating of banking crises.

Regarding Financial Stability, many global, regional and governmental bodies are established for its promotion. The Financial Stability Board (FSB) is established to address financial system susceptibilities and to drive the development and implementation of strong regulatory, supervisory, and other policies which enhance financial stability. Also, the Financial Stability Forum (FSF) has been set up by the G-7 in the wake of the Asian crisis in 1999, with an expanded membership (drawn mainly from the G-20).

In US, the legislation Restoring American Financial Stability Act of 2010 focuses on how to promote the financial stability. The UK Financial Services Authority (FSA) requires stricter capital rules than those proposed by the Basel Committee on Banking Supervision (BCBS). The European Central Bank (ECB) is in charge of monitoring and assessment of financial stability. Presently, the Committee of European Banking Supervisors (CEBS) provides regular bank sector analysis, performs assessments on banking risks, to be reported to the European Union political institutions.

Schinasi (2004) lists the key principles for defining financial stability as a generic concept, embodying the varied aspects of the financial system. The author addresses that financial stability relates not only to the absence of financial distress but also to the capability of the financial system to limit, contain, and deal with such situations. Schinasi (2006) addresses "stability" as the ability of financial system to resolve systemic risks. He argues that financial system is stable if the system is capable to perform three key functions: 1) allocation of resources from savers to investors; 2) assessment, pricing, and allocation of financial risks; and 3) absorption of financial and economic shocks.

Amidu \& Wolfe (2009) analyzes a panel dataset of 978 banks, during the period 2000-2007. Macro data is obtained from the World Development Indicator of the World Bank and International Financial Statistics database. They use H-statistic and the Lerner index as measures of the degree of competition in the banking sector, employ three stage least squares (3sls) estimation techniques, and investigate the significance of diversification in the competition-stability relationship. The core finding is that competition increases stability as diversification across and within both interest and non-interest income generating activities of banks increases.

Dobravolskas \& Seiranov (2011) investigates the reasons of financial instability, during the 2007- 2008 crisis and studies the ways of rebuilding financial stability in the process of post-crisis regulatory reforms. Findings show that violation of stability is a result of deregulation processes in major financial markets since 1980s on the one hand, a result of inadequacy of national micro-prudential regulators on the other hand. The article studies how these targets are met in post-crisis regulatory reforms, in USA, the European Union and Lithuania.

Demirgüç-Kunt \& Detragiache (2011) studies the effect of compliance with the Basel core principles for effective banking supervision on bank soundness. Using data for more than 3000 banks in 86 countries, the authors find that neither the overall index of compliance with the Basel core principles nor the individual components of the index are robustly associated with bank risk measured by Z-scores. This may cast doubt on the usefulness of the Basel core principles in ensuring bank soundness.

Shoenmaker \& Wagner (2011) argues that cross-border banking brings about various benefits and costs for financial stability, as applied on the European banks. Results show that countries with large banks (UK and Germany) are well diversified, while New Member States (NMS) are highly dependent on a few west European banks and thus vulnerable to contagion effects. Besides, Wen \& Yu (2013) elaborates the effects of bank stability on market concentration, financial deepening, bank income structure and international debt situation by using panel data for 18 emerging countries. Results supports that concentration affects financial stability in banking industry.

Regarding the current study, comparing with previous work, it's important to pinpoint some differences that may justify its importance, as follows:

- $\quad$ Papers concerning with size effect tend to investigate its effect in terms of bank efficiency, while the current paper analyzes this effect in terms of bank systemic risk.

- The most of previous work - in the field of financial stability - focuses on its determinants, while the current study investigates its effects.

- The current paper combines size effect, financial stability and equity return, shedding a light on their effects on systemic risk. It tries to develop a framework for its economic, financial and market determinants.

\section{Data Description and Hypotheses Developing}

Regarding required data regarding bank systemic risk, size, financial stability and equity return. Systemic Risk 
(SR) is measured by VaR that indicates the maximum loss in stock price within 0.99 confidence interval, as follows:

$$
V a R=\text { the maximum loss in stock price within } 0.99 \text { confidence interval }
$$

Bank size is measured by the square root of its assets (SA), the square root of its deposits (SD) and the square root of its loans (SL), as follows:

$$
S A=\sqrt{ } A
$$

where A denotes the bank assets (in L.E. billion).

$$
S D=\sqrt{ } D
$$

where D denotes the bank deposits (in L.E. billion).

$$
S L=\sqrt{ } L
$$

where L denotes the bank loans (in L.E. billion).

Financial stability is measured by Z-score that indicates the number of standard deviations that a bank's profit must fall to drive it into insolvency. This could be shown as follows:

$$
Z=(R O A+E / A) / \sigma_{R O A}
$$

where ROA is return on assets, $\mathrm{E} / \mathrm{A}$ denotes the equity to asset ratio and $\sigma_{\mathrm{ROA}}$ is the standard deviation of return on assets.

Equity return (ER) is measured by average change in the bank's stock price, as follows:

$$
E R=\left(B P_{t}-B P_{t-1}\right) / B P_{t-1}
$$

where $\mathrm{BP}_{\mathrm{t}}$ denotes the bank's stock price at the end of period $\mathrm{t}$ and $\mathrm{BP}_{\mathrm{t}-1}$ denotes the bank's stock price at the end of period $\mathrm{t}-1$.

This paper tries to test the following three hypotheses:

- There's no significant effect of "size" on "systemic risk", as applied on listed banks in Egyptian exchange.

- There's no significant effect of "financial stability" on "systemic risk", as applied on listed banks in Egyptian exchange.

- There's no significant effect of "equity return" on "systemic risk", as applied on listed banks in Egyptian exchange.

Testing hypotheses requires testing the significance of the following:

$$
V a R=f(S A, S D, S L, Z, E R)
$$

This means that alternative hypothesis $\mathrm{H}_{\mathrm{a}}: \beta \# 0$, versus null hypothesis $\mathrm{H}_{\mathrm{b}}: \beta=0$, where $\beta$ is the regression coefficient of the above-shown function.

\section{Results of Empirical Study}

The following table illustrates descriptive statistics of stock return for a sample of 11 banks (out of 14 banks listed in the Egyptian exchange during the research period) during the period from 2003 to 2013:

Table 2. Descriptive statistics of banks' stock returns from 2003 to 2013

\begin{tabular}{cccccccc}
\hline Period & Bank & Min. & Max. & Mean & S. Deviation & Lowest $1 \%$ & Highest $1 \%$ \\
\hline Pre-Crisis & 1 & -0.5415 & 0.2704 & 0.0229 & 0.1109 & -0.1027 & 0.2136 \\
& 2 & -0.2977 & 0.4327 & 0.0114 & 0.1026 & -0.1283 & 0.2153 \\
& 3 & -0.2244 & 0.4082 & 0.0145 & 0.1061 & -0.1429 & 0.2356 \\
& 4 & -0.1675 & 0.4466 & 0.0159 & 0.1144 & -0.1504 & 0.2778 \\
& 5 & -0.5687 & 0.4501 & 0.0179 & 0.1253 & -0.1009 & 0.2224 \\
& 6 & -0.2806 & 0.5127 & 0.0269 & 0.1342 & -0.1879 & 0.2861 \\
& 7 & -0.5671 & 0.8566 & 0.0303 & 0.2020 & -0.2508 & 0.3880 \\
& 8 & -0.5890 & 0.7717 & 0.0343 & 0.1709 & -0.1354 & 0.3183 \\
& 9 & -0.2866 & 0.4158 & 0.0132 & 0.1036 & -0.1270 & 0.2509 \\
& 10 & -0.2607 & 0.4813 & 0.0100 & 0.0869 & -0.0626 & 0.2206 \\
& 11 & -0.3784 & 0.5046 & 0.0197 & 0.1257 & -0.1389 & 0.2629 \\
\hline
\end{tabular}




\begin{tabular}{|c|c|c|c|c|c|c|c|}
\hline \multirow[t]{11}{*}{ During-Crisis } & 1 & -0.4163 & 0.2823 & -0.0035 & 0.1417 & -0.3238 & 0.2083 \\
\hline & 2 & -0.2399 & 0.2468 & -0.0047 & 0.0937 & -0.1771 & 0.1439 \\
\hline & 3 & -0.5000 & 0.3092 & -0.0058 & 0.1287 & -0.1953 & 0.2704 \\
\hline & 4 & -0.3243 & 0.3882 & -0.0137 & 0.1352 & -0.2506 & 0.2291 \\
\hline & 5 & -0.2913 & 0.3926 & 0.0028 & 0.1370 & -0.1997 & 0.2758 \\
\hline & 6 & -0.3521 & 0.5319 & -0.0049 & 0.1684 & -0.2612 & 0.3422 \\
\hline & 7 & -0.3330 & 0.4204 & -0.0005 & 0.1428 & -0.2549 & 0.2499 \\
\hline & 8 & -0.4080 & 0.2617 & -0.0055 & 0.1040 & -0.1930 & 0.1787 \\
\hline & 9 & -0.2685 & 0.4039 & 0.0038 & 0.1226 & -0.2050 & 0.2536 \\
\hline & 10 & -0.2020 & 0.1874 & -0.0045 & 0.0476 & -0.1357 & 0.0531 \\
\hline & 11 & -0.3335 & 0.3424 & -0.0036 & 0.1222 & -0.2196 & 0.2205 \\
\hline \multirow[t]{11}{*}{ All Period } & 1 & -0.5415 & 0.2823 & 0.0106 & 0.1264 & -0.2402 & 0.2058 \\
\hline & 2 & -0.2977 & 0.4327 & 0.0038 & 0.0985 & -0.1627 & 0.1503 \\
\hline & 3 & -0.5000 & 0.4082 & 0.0051 & 0.1171 & -0.1611 & 0.2668 \\
\hline & 4 & -0.3243 & 0.4466 & 0.0015 & 0.1253 & -0.1847 & 0.2656 \\
\hline & 5 & -0.5687 & 0.4501 & 0.0109 & 0.1306 & -0.1667 & 0.2315 \\
\hline & 6 & -0.3521 & 0.5319 & 0.0137 & 0.1495 & -0.2352 & 0.2933 \\
\hline & 7 & -0.5671 & 0.8566 & 0.0160 & 0.1770 & -0.2482 & 0.3591 \\
\hline & 8 & -0.5890 & 0.7717 & 0.0158 & 0.1446 & -0.1694 & 0.2345 \\
\hline & 9 & -0.2866 & 0.4158 & 0.0088 & 0.1126 & -0.1548 & 0.2418 \\
\hline & 10 & -0.2607 & 0.4813 & 0.0033 & 0.0715 & -0.0951 & 0.1062 \\
\hline & 11 & -0.4288 & 0.5077 & 0.0089 & 0.1253 & -0.1818 & 0.2355 \\
\hline
\end{tabular}

Source: collected and processed by the researcher.

Descriptive statistics indicate that the returns of stock prices range from $1 \%$ to $3.43 \%$ (for the pre-crisis period), from $-1.37 \%$ to $0.38 \%$ (for the during-crisis period) and from $0.15 \%$ to $1.6 \%$ (for the all period). Besides, VaR within 0.99 confidence interval range from $-25.08 \%$ to -6.26 (for the pre-crisis period), from $-13.57 \%$ to $-32.38 \%$ (for the during-crisis period) and from $-24.82 \%$ to $-9.51 \%$ (for the all period).

The following table illustrates the effects of bank size, financial stability and equity return on systemic risk, for the pre-crisis, during-crisis and all the period, as follows:

Table 3. Testing hypothesis by cross sectional analysis using monthly return

\begin{tabular}{|c|c|c|c|c|c|c|c|c|}
\hline Period & $\alpha$ & SA & SD & SL & $\mathbf{Z}$ & ER & $\mathbf{F}$ & $\mathbf{R}^{2}$ \\
\hline Pre-Crisis & $\begin{array}{c}\mathbf{0 . 0 0 0 4} \\
(0.0001)^{*}\end{array}$ & --- & --- & $\begin{array}{c}\mathbf{- 0 . 0 0 0 9} \\
(0.005)^{* * *}\end{array}$ & $\begin{array}{c}\mathbf{0 . 0 0 1 8} \\
(0.001)^{* * *}\end{array}$ & --- & $\begin{array}{c}\mathbf{2 2 . 5 0 2} \\
(0.001)^{* * * *}\end{array}$ & $\begin{array}{c}\mathbf{0 . 8 3 3} \\
(0.0658)\end{array}$ \\
\hline Post-Crisis & $\begin{array}{c}\mathbf{0 . 0 0 0 2} \\
(0.0001)^{*}\end{array}$ & --- & --- & $\begin{array}{c}-\mathbf{0 . 0 0 1 1} \\
(0.007)^{* * *}\end{array}$ & $\begin{array}{c}\mathbf{- 0 . 0 0 3 9} \\
(0.001)^{* * *}\end{array}$ & --- & $\begin{array}{c}\mathbf{4 1 . 6 5 2} \\
(0.001)^{* * *}\end{array}$ & $\begin{array}{c}\mathbf{0 . 8 8 1} \\
(0.0752)\end{array}$ \\
\hline All Period & $\begin{array}{c}\mathbf{0 . 0 0 0 3} \\
(0.0001)^{* *}\end{array}$ & $\begin{array}{c}\mathbf{- 0 . 0 0 1} \\
(0.003)^{* * *}\end{array}$ & --- & --- & $\begin{array}{c}\mathbf{- 0 . 0 0 2 6} \\
(0.001)^{* * *}\end{array}$ & -- & $\begin{array}{c}\mathbf{4 4 . 4 4 7} \\
(0.001)^{* * *}\end{array}$ & $\begin{array}{c}\mathbf{0 . 8 8 8} \\
(0.0674)\end{array}$ \\
\hline
\end{tabular}

Note. Each cell contains the estimated parameters, with standard error between brackets, where * denotes p-value of $10 \%$, ** denotes $5 \%$ and $* * *$ denotes $1 \%$.

The above-shown table indicates that null hypothesis could be rejected for the first and second hypotheses. So, the alternative hypothesis may be accepted. This means that each of size and financial stability may affect systemic risk, with $\mathrm{R}^{2}$ ranged from $83.3 \%$ to $88.8 \%$ at p-value of $1 \%$ at least. It's important to consider the negative signs of size coefficients and to investigate the signs of Z-Score coefficients that are positive for the pre-crisis period and negative for the during-crisis and all research periods. To check the previous results, 
robustness check has been conducted (using time series analysis by daily returns) and provides the following results:

Table 4. Robustness check by time series analysis using daily return

\begin{tabular}{|c|c|c|c|c|c|}
\hline Bank & $\alpha$ & $\beta_{1}$ & $\beta_{2}$ & F & $\mathbf{R}^{2}$ \\
\hline \multirow{2}{*}{1} & 0.053 & -0.021 & -0.0057 & 14.91 & 0.651 \\
\hline & $(0.031)^{* *}$ & $(0.006)^{* * *}$ & $(0.005)^{* * *}$ & $(0.005)^{* * *}$ & (0.1798) \\
\hline \multirow{2}{*}{2} & -0.079 & -0.002 & -00042 & 2.84 & 0.654 \\
\hline & $(0.041)^{* *}$ & $(0.001)^{*}$ & $(0.004)^{*}$ & $(0.005)^{*}$ & (0.039) \\
\hline \multirow{2}{*}{3} & -0.019 & -0.009 & -00037 & 4.86 & 0.391 \\
\hline & $(0.057)^{* *}$ & $(0.003)^{*}$ & $(0.006)^{*}$ & $(0.067)^{*}$ & $(0.227)$ \\
\hline \multirow{2}{*}{4} & 0.055 & -0.013 & \multirow{2}{*}{---} & 7.578 & 0.486 \\
\hline & $(0.029)^{* *}$ & $(0.005)^{* *}$ & & $(0.005)^{* *}$ & (0.1633) \\
\hline 5 & --- & --- & --- & --- & --- \\
\hline \multirow{2}{*}{6} & -0.048 & 0.008 & 0.0013 & 3.14 & 0.473 \\
\hline & $(0.049)^{* *}$ & $(0.004)^{*}$ & $(0.001)^{*}$ & $(0.005)^{*}$ & $(0.146)$ \\
\hline \multirow{2}{*}{7} & -0.111 & -0.014 & \multirow{2}{*}{--- } & 4.137 & 0.341 \\
\hline & $(0.0981)^{*}$ & $(0.007)^{*}$ & & $(0.076)^{*}$ & $(0.266)$ \\
\hline \multirow{2}{*}{8} & -0.009 & -0.004 & -0.00249 & 14.91 & 0.607 \\
\hline & $(0.028)^{* *}$ & $(0.013)^{* *}$ & $(0.010)^{* *}$ & $(0.005)^{* *}$ & (0.1798) \\
\hline \multirow{2}{*}{9} & -0.011 & -0.012 & -0.0023 & 14.75 & 0.597 \\
\hline & $(0.039) * *$ & $(0.006)^{* *}$ & $(0.002)^{* *}$ & $(0.006)^{* *}$ & $(0.1805)$ \\
\hline 10 & --- & --- & --- & --- & --- \\
\hline 11 & --- & --- & --- & --- & --- \\
\hline
\end{tabular}

Note. Each cell contains the estimated parameters, with standard error between brackets, where $*$ denotes p-value of $10 \%$, $* *$ denotes $5 \%$ and $* * *$ denotes $1 \%$.

The above-shown table illustrates the effect of "financial stability" on "systemic risk" using quadratic regression technique, with $\mathrm{R}^{2}$ ranged from $34.1 \%$ to $65.4 \%$, for 8 banks, while no effect seems to be significant for the other 3 banks. Results indicate that VaR is positively affected by Z-score to a certain point, after which it turns out to be declining.

\section{Summary and Concluded Remarks}

This paper attempts to propose a framework for assessing the systemic risk of Egyptian banks. This framework elaborates economic, financial and market aspects, as the main three determinants of the systemic risk. This has been conducted by analyzing the effects of "size", "financial stability" and "equity return" on the systemic risk of Egyptian banks, using a sample of 11 banks (out of 14 banks listed in the Egyptian exchange), and covering the period from January 2003 to December 2013.

Systemic risk could be measured by "Value at Risk" that expresses the maximum loss within a q\%-confidence interval during a certain period of time. Determinants of systemic risk to be examined, may be economic, as "size" in terms of TBTF rule. They may be financial, where "financial stability" is addressed as the ability of financial system to resolve systemic risks. Besides, "equity return" could be used as a market determinant.

Results indicate that size and financial stability may affect systemic risk of Egyptian banks during research period, using cross sectional analysis, by monthly returns (1-month, $0.99 \mathrm{VaR}$ ) for the pre-crisis, during-crisis and all the research periods. Also, robustness check investigates the effect of financial stability, using time series analysis, by daily returns (1-day, $0.99 \mathrm{VaR}$ ). These results have important implications for macro prudential regulation and banking supervision. In this context, results show that both of "size" and "financial stability" may 
explain "systemic risk", while there's no evidence about the effect of "equity return".

Results don't support the TBTF rule, as they indicate that large banks has a higher systemic risk, while size effect has been supported by works of Adrian \& Brunnermeier (2011), Borri et al. (2014) and Laeven et al. (2014). Moreover, banks with high financial stability seem to have lower systemic risk to a certain level. This may need to be more elaborated by investigating whether there's an optimal level of financial stability, in terms of its potential impact on systemic risk.

\section{References}

Acharya, V., Pedersen, L., Philippon, T., \& Richardson, M. (2010). Measuring systemic risk. NYU Working Paper.

Adrian, T., \& Brunnermeier, M. (2011). CoVaR. Working Paper, Federal Reserve Bank of New York.

Alber, N. (2014). Size effect, seasonality, attitude to risk and performance of Egyptian Banks. International Business Research, 7(1), 92-93.

Amidu, M., \& Wolfe, S. (2009). Bank competition, diversification and financial stability. $22^{\text {nd }}$ Australasian Finance and Banking Conference 2009. Retrieved fromhttp://ssrn.com/abstract=1341863

Ang, A., \& Longstaff, F. (2013). Systemic sovereign credit risk: Lessons from the U.S. and Europe. Journal of Monetary Economics, 60(5), 493-510. http://dx.doi.org/10.1016/j.jmoneco.2013.04.009

Anis, O., \& Sami, R. (2012). Financial liberalization (FL), Environment variables and cost efficiency of tunisian banking system. Journal of Applied Finance and Banking, 2(5), 1-25.

Bartholomew, P., \& Whalen, G. (1995). Fundamentals of systemic risk. In G. Kaufman (Ed.), Research in financial services: Banking, financial markets, and systemic risk (Vol. 7, pp. 3-17). Greenwich, Conn: Jal.

Berger, A., Bouwman, C., Kick, T., \& Schaeck, K. (2011). Bank risk taking and liquidity creation following regulatory interventions and capital support. Deutsche Bundesbank Discussion Paper, Series 2, No 05/2010.

Borri, N., Caccavaio, M., Di Giorgio, G., \& Sorrentino, A. (2014). Systemic risk in the Italian banking industry. Economic Notes Review of Banking, Finance and Monetary Economics, 43(1), 21-38.

Carvallo, O., \& Kasman, A. (2005). Cost efficiency in the Latin American and Caribbean banking systems. Journal of International Financial Markets Institution and Money, 15, 55-72. http://dx.doi.org/10.1016/j.intfin.2004.02.002

Central Bank of Egypt. (2013). Economic Review.

Chaudron, R., \& De Haan, J. (2014). Identifying and dating systemic banking crises using incidence and size of bank failures. DNB Working Paper \# 406, Netherlands Bank, Research Departement.

De Jonghe, O. (2010). Back to the basics in banking: A micro - analysis of banking system stability. Journal of Financial Intermediation, 19(3), 387-417. http://dx.doi.org/10.1016/j.jfi.2009.04.001

Demirgüç-Kunt, A., \& Detragiache, A. (2011). Basel core principles and bank soundness does compliance matter? Journal of Financial Stability, 7(4), 179-190. http://dx.doi.org/10.1016/j.jfs.2010.03.003

Dobravolskas, A., \& Seiranov, J. (2011). Financial stability as the goal of post-crisis regulatory reforms. Business Systems and Economics, 1(1), 101-114.

Dragan, O., Batrancea, I., \& Bechis, L. (2013). Systemic risk in banking sector. The USV Annals of Economics and Public Administration, 1(17).

Huang, X., Zhou, H., \& Zhu, H. (2009). A framework for assessing the systemic risk of major financial institutions. Journal of Banking and Finance, 33, 2036-49. http://dx.doi.org/10.1016/j.jbankfin.2009.05.017

Huang, X., Zhou, H., \& Zhu, H. (2010). Measuring systemic risk contributions. BIS Working Paper. http://dx.doi.org/10.1596/1813-9450-5439

Kaufman, G. (1995). Bank failures, systemic risk, and bank regulation. Conference on Public Regulation of Depository Institutions, Koc University, Istanbul, Turkey.

Laeven, L., Ratnovski, L., \& Tong, H. (2014). Bank size and systemic risk. IMF Staff Discussion Note, International Monetary Fund.

Lehar, A. (2005). Measuring systemic risk: A risk management approach. Journal of Banking and Finance, 29, 2577-603. http://dx.doi.org/10.1016/j.jbankfin.2004.09.007 
Lucas, A., Schwaab, B., \& Zhang, X. (2011). Conditional probabilities for Euro area sovereign default risk. Tinbergen Institute Discussion Paper \# 11-176/2/DSF29, Tinbergen Institute.

Markose, S., Giansanti, S., Gatkowski, M., \& Shaghaghi, A. (2010). Too interconnected to fail: Financial contagion and systemic risk in network model of CDS and other credit enhancement obligations of US banks. Essex Working Paper.

Martinez-Jarmillo, S., Perez, O., Avila, E., \& Lwila, D. (2010). Systemic risk, financial contagion and financial fragility. Journal of Economics Dynamics and Control, 34, 2358-74. http://dx.doi.org/10.1016/j.jedc.2010.06.004

Sahut, J., \& Mili, M. (2009). Determinants of banking distress and merger as strategic policy to resolve distress. Retrieved from http://ssrn.com/abstract $=1343814$

Schaeck, K., Buston, C., \& Wagner, W. (2013). The two faces of interbank correlation. EBC Discussion Paper \# 2013-015. Tilburg: European Banking Center.

Schinasi, G. (2004). Defining financial stability. IMF Working Paper, WP/04/187, International Capital Markets Department, International Monetary Fund.

Schinasi, G. (2006). Safeguarding financial stability: Theory and practice. Washington, D.C.: International Monetary Fund.

Segoviano, A., \& Goodhart, C. (2009). Banking stability measures. Financial Markets Group Working Paper, London School of Economics and Political Science.

Shoenmaker, D., \& Wagner, W. (2011). The impact of cross-border banking on financial stability. Tinbergen Institute Discussion Paper \# 11-054/2/DSF18, Tinbergen Institute.

Wen, S., \& Yu, J. (2013). Banking stability, market structure and financial system in emerging countries. Journal of Applied Finance \& Banking, 3(3), 1-13.

\section{Copyrights}

Copyright for this article is retained by the author(s), with first publication rights granted to the journal.

This is an open-access article distributed under the terms and conditions of the Creative Commons Attribution license (http://creativecommons.org/licenses/by/3.0/). 